\title{
“なま”および蒸煮蛋白食品のプロテアーゼによる 被分解性について Enzymic Proteolysis of Raw and Steamed Meat
}

(昭 和 39 年 12 月 15 日受理)

\author{
春旦井愛子 \\ (Aiko Kasugai)
}

The investigation of the effect of cooking on the degree of proteolysis of various raw meat by several commercial proteinase preparations were investigated and it was found that chopped raw meat was digested by the enzyme preparations more easily than steamed chop meat and, of the meats tested here (12 kinds including seafoods and hen's eggs), the effect of cooking to improve the proteolysis degree was found only with hen's eggs.

緒言

プロテアーゼは種類が多く，また同一プロテアーゼで も基質蛋白の種類や作用条件などにより，分析生成物や 分解度が異なる。

近年酵素化学の発展にともない酵素の食品への利用が 広く研究され，種々の醅素剤が市販されるよ5になった。 そこで市販プロテアーゼ剤による，なま並びに蒸著した 蛋白食品の蛋白分解度について試験を扣こなった。

一般に蛋白質は天然の状態ではプロテアーゼにより分 解され難いか，または全く分解されずに加熱などにより 変性してはじめて容易に分解されるといわれている。し かしわれわれは“さしみ”などのよ5に，新鮮な魚介類 などを䬶することがしばしばある。そこで市肘プロテア 一ゼを用い，主に生鮮魚介類，鳥獣肉並びにそれらを蒸 煮したときの蛋白分解度について検討した。なお比較の ため数種の植物性食品中の蛋白についても同じく検討し た。これらの結果について報告する。

\section{試料および方法}

\section{I 供試食品}

なるべく新鮮な市販魚介類, 鳥獣肉類を実験に供した。 な打比較のため米，麦拉よび大豆なども実験に供した。

\section{II 供試食品の処理}

実験にはすべて可食部 $(100 \mathrm{~g})$ を用いた。獣肉は市販 のミンチ肉を用い, 魚介類（魚類は皮を，イカは表面の 5す皮をはぎとった。）と鳥類はいずれも“Veritas”肉 婏機（プレートの穴の直径 $1.6 \mathrm{~mm}$ ) によりミンチし たのち用いた。このミンチした肉を 2 等分し, その一半
はそのまま（以後これをなまと呼ら゙）冷所 $\left(10^{\circ} \mathrm{C}\right)$ に保 ち, 他の一半は 5 分間蒸著した。蒸煮中, 水分の浸入を 防ぐため, ミンチ肉をビーカーに入れ，その上部を防湿 セロファン紙で包んだ姼蒸煮した。蒸煮によりミンチ肉 は塊となるのでこれを乳鉢内でつぶしたのち，実験に供 した（蒸竟肉）。なま謟卵の場合は卵白と卵黄とに分け， それぞれガーゼ布でろ過したのち実験に供した。一方水 煮卵の場合は通常ど扣り卵を $100^{\circ} \mathrm{C}, 15$ 分間水煮したの ち、卵白と卵黄に分け，それぞれ5らごしにかけたのち 実験に供した。

米麦の場合は，粒をビーカーに入れ，それに等重量の 水を加え， $40^{\circ} \mathrm{C}, 1$ 時間浸漬したのち，浸沾水とともに 乳鉢でまさいした (なま米麦)。蒸煮の場合は同じ条件で ビーカー内で水に米または麦を浸洁し，ビーカーの上部 を防湿セロファン紙で包んだのち， $100^{\circ} \mathrm{C}, 30$ 分間蒸煮 した。蒸煮したのち, 通常の忺飯の要領で蒜器に入れた ままさらに15分間放置した（蒸募米または麦）。なお， 蒸募米または麦は粒のままそれをさらに乳鉢でつぶした ものとについてそれぞれ実験した。大豆の場合は 4 倍量 の水に 1 夜浸渍したのち, 十分水を切り, 得られる吸水 大豆を粉砕機で粉砕した（なま大豆）。また粉硴した大 豆を45分間蒸煮したのち, 前記同様さらに15分間蒸器内 に放置したものを蒸煮大豆として実験に供した。

III 酵素溶液の調製

供試酵素郕は作用最適 $\mathrm{pH}$ が酸性側の Rhizopus niveus, Aspergillus niger, 中性扰よびアルカリ性側のBac. Subtilis, 微アルカリ性側の Pancreatin の 4 種の䣲素剤 でこれら酵素凨中に共存する主な他種酵素並びにその酵 素力は第 1 表のとおりであった。まずこれら酵素剤を 2 


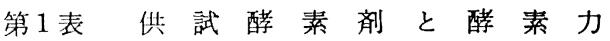

\begin{tabular}{|c|c|c|c|c|c|c|}
\hline \multirow{2}{*}{ 製品名と給源 } & \multicolumn{2}{|c|}{ プロテアーゼ* } & \multicolumn{3}{|c|}{ 共存酵素とその酵素力 単位 $/ \mathrm{g}$} & \multirow{2}{*}{ 製造会社名 } \\
\hline & 単位 $/ g$ & 最適 $\mathrm{pH}$ & $\begin{array}{l}\text { セルラーゼ *** } \\
\text { ヘミセルラーゼ }\end{array}$ & アミラーゼ & リパーゼ & \\
\hline $\begin{array}{l}\text { セロシン A.P } \\
\text { Aspergillus niger }\end{array}$ & 32,000 & 3. 0 & 2,730 & + & - & 上田化学工業㑣 \\
\hline $\begin{array}{l}\text { サン プロ - ゼ } \\
\text { Rhizopus niveus }\end{array}$ & 57,000 & 3. 0 & 540 & $\begin{array}{l}\text { グルクアミラー } \\
\text { ゼ } 1,150 \\
\text { (糖化力) }\end{array}$ & - & 阪急酵素 (休 \\
\hline $\begin{array}{l}\text { プロテオリクィファーゼ } \\
\text { Bac. subtilis }\end{array}$ & 48,200 & $7 \sim 10$ & - & $\begin{array}{c}\alpha-ア ミ テ ー セ ゙ \\
32,000 \\
(\text { リントナー) }\end{array}$ & - & 上田化学工業(㑣 \\
\hline $\begin{array}{l}\text { パンクレアチン** } \\
\text { Pancreatin }\end{array}$ & 52,600 & 8.6 & - & $\begin{array}{c}\alpha-ア ミ ラ ー セ ゙ ~ \\
7,500 \\
(\text { 糊精化力) }\end{array}$ & 册 & 日本藏器製薬㑣 \\
\hline
\end{tabular}

* 醉素力単位はいずれもそれぞれの最適 $\mathrm{pH}$ でFolin 法変法によって測定した值。

** Pancreatin（偳造李用）のプロテアーゼ力は局法の4.72倍，アミラーゼ力は局法の3.75倍であった。

*** ヒルラーゼ,へミセルラーゼ力は CMC 分解力で示した。

\%水溶液とし (Aspergillus niger の孙は $3 \%$ 水溶液), $30^{\circ} \mathrm{C}, 30$ 分間放置したのち，关の!浴谁圭导らに水で10 倍に希秋したもの圭醉素溶液上した。

IV 址的分解条作とそれの分解度の测定

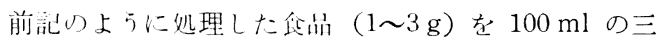
解フラスコに入机，专机に $20 \mathrm{ml}$ の前記醉素溶液を加克 て $30^{\circ} \mathrm{C}, 1$ 夜 (17〜18㭙擝)，トルオール存在下で放置し

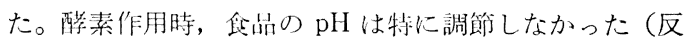

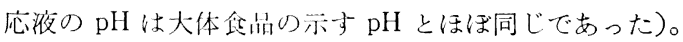
また添加した醉素の酵索力はいずれもこの条件( $\mathrm{pH}$ 6.0)

第 1 闵 プロテアーゼによるミルクカゼインの TCA 可溶性:化度

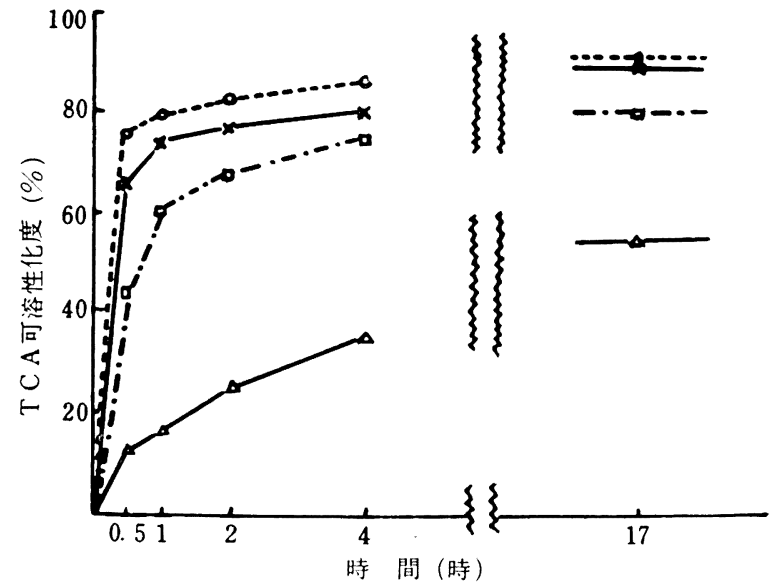

ミルクカゼイン $2 \% 10 \mathrm{ml}$ に種々のプロテアーゼ $10 \mathrm{ml}$ を加 光（pH6.0) $30^{\circ} \mathrm{C}$ で反応させた。

Asp. niger のプロテアーゼは $0.3 \%$ ，その他のプロテアーゼ は $0.2 \%$ とした。

$\longrightarrow \times$ Pancreatin

..... $\bigcirc \cdots$.... Bac. subtilis

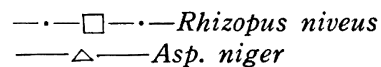

で食品中の蛋白と等㫣のカゼインを 1〜2 時間内に容易 に分解しらる活性:であって，それのカゼイン分解の限度 は17日年間反応後に TCA 可溶性化度で测定した場合,

Rhizopus niveus, Bac. subtilis, Pancreatin の 3 種の醉 素では約 80〜90\%，Aspergillus niger では55\%であ った（第 1 図）。醉素反応後，反応液を $10,000 \times \mathrm{g}$ で10 分間遠沈し，その上澄液につき蛋白の TCA 可溶性化度 とアミノ基生成度合とを測定した。

（i）蛋白の TCA 可溶性化度の測定：前記食品の醉 素反応液の上澄に TCA 混液 $\left(0.66 \mathrm{M} \mathrm{CCl}_{3} \mathrm{COOH}, 1.32\right.$

$\left.\mathrm{M} \mathrm{CH}_{3} \mathrm{COONa}, 1.98 \mathrm{M} \mathrm{CH}_{3} \mathrm{COOH}\right)$ を等量に添 加し, $30^{\circ} \mathrm{C}, 30$ 分間後 $10,000 \mathrm{~g}$ で10分間遠沈した。 この上澄液または希釈夜 $5 \mathrm{ml}$ に Folin 氏試薬の 5 倍希积液 $1 \mathrm{ml}$ を加え, $30^{\circ} \mathrm{C}, 30$ 分後発した青色を 比色 $(660 \mathrm{~m} \mu$ の吸光度, エルマ光電比色計 N 5 型, 吸収セル厚さ $1 \mathrm{~cm}$ ) し, それをチロシン相当 量であらわした。一方供試酵萦夜, 供試食品それぞ れ単独に, 同一条件で処理した場合に得られるチ口 シン相当量を前記 TCA 可溶性化部分のチロシン相 当量から差引いた值を消化部分とした。な拉全チロ シン量は十分摩确して供試食品 $1 \sim 3 \mathrm{~g}$ に $0.05 \mathrm{~N}$ $\mathrm{NaOH}$ を含む $0.4 \mathrm{M} \mathrm{Na}_{2} \mathrm{CO}_{3} 20 \mathrm{ml}$ 加兄, $100^{\circ} \mathrm{C}$ 30 分間加熱した液に直接 Folin 氏試薬を加えて定量 した場合の值を 100 とし，これに対する前記 TCA 可溶性消化部分の比をもって TCA 可溶性化度とし た。

（ii）遊離アミノ基の生成度合 : 直接前記醳素反 応液について生成した遊離アミノ基量をニンヒドリ ン法により定量した。適宣希採した反応液 $1 \mathrm{ml} k$ ニンヒドリン液（ニンヒドリン $800 \mathrm{mg}$ とヒドリン 
ダンチン $120 \mathrm{mg}$ にメチルセロソルブ $30 \mathrm{ml}$ を加えて とかし、これに N/10 クェン酸緩衝液 $(\mathrm{pH} 5.0) 10 \mathrm{ml}$ を加える） $1 \mathrm{ml}$ を加光, 15 分間沸腾水中で加熱後水冷 し，50\%(v/v) アルコール $15 \mathrm{ml}$ 加えて振とうしたの ち, それについて $570 \mathrm{~m} \mu$ で前記と同じ光電比色計（吸 収セル直径 $18 \mathrm{~mm}$ ) を用いて吸光度を測定した。一方 全アミノ基の総量は供試食品 $100 \sim 300 \mathrm{mg}$ に $6 \mathrm{~N} \mathrm{HCl}$ $2 \mathrm{ml}$ を加え，封管中で $105^{\circ} \mathrm{C} ， 24$ 時間加熱分解したの ち， $\mathrm{HCl}$ を除き，その残渣を溶解し（pH 5.0)，それに ついて前記同様ニンヒドリン法によりアミノ基量を測定 しここれ 100 として前記值と比較し遊離アミノ基生成 度合を求めた。

\section{結果}

I 魚介類について

（1）食品の蒸煮，切り方などと蛋白分解率との関係：
新鮮な魚介類は“さしみ”などにしてなまのまま食用に 供している。そこで新鮮魚介類（なまの状態の蛋白質） に対し，プロテアーゼがどの程度まで作用するかを検討 するため，次の奏䮖を行なった。かみそり刃で切片（約 $1 \mathrm{~cm} \times 4 \mathrm{~mm} \times 2 \mathrm{~mm}$ ) にした魚肉（マグロ），それと蒸 煮したものとに多量のプロテアーゼ (Bac. subtilis) を 加光, 径時的にその分解度を調べた。な打比較のためミ ンチしたマグロについても同じ条件で試験した。マグロ の蛋白分解の状態は TCA 可溶性化度と遊離アミノ基生 成度合とで測定した（第 2 図）。すなおちなまの方が妸 片の場合でもミンチした場合でも蒸少した方より，いず れの测定でも分解度が高かった。いいかえればミンチし たものでも切片の場合と同様なまと䳫堂との差が明らか に示された。以後の実験においてて供試战品の均一性を 得るためミンチしたものを使用することにした。

（2）種々魚介類の場合：魚類ではイボダイ（一名ウオ

第 2 図 食品の蒸煮, 切り方とプロテアーゼによる蛋白分解率との関倸
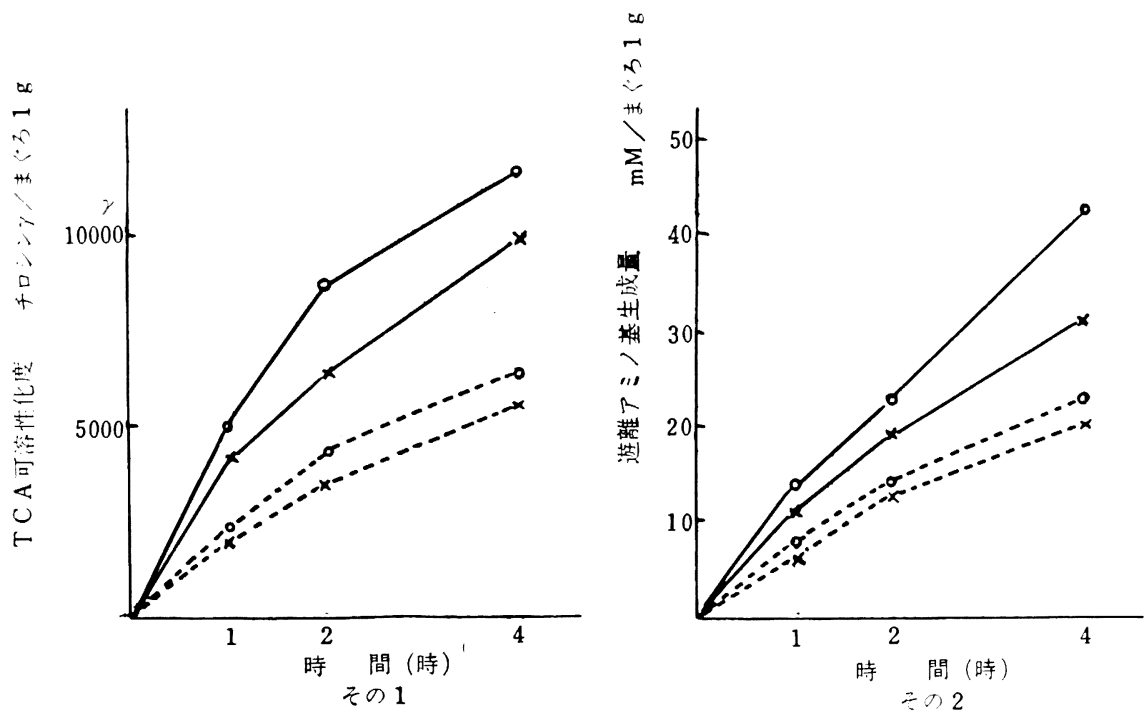

まぐろ $15 \mathrm{~g}$

Bac. subtilis (1000単位 $/ \mathrm{ml}) 100 \mathrm{ml}$ ) $\} 30^{\circ} \mathrm{C}$ にて分解 ( $\mathrm{pH} \mathrm{5.8)}$

一……蒸煮 $\}$ ミンチにしたまぐろ

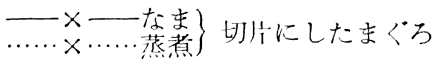

ゼ), アジ，タイ，ハマチ，マグロ，介類ではアワビ， その他スルメイカ扰びェビ（シラサエビ）の計 8 種を 選んだ。ミンチしたこれら魚介類をなまと蒸煮とに区別 し，それらに 4 種のプロテアーゼをそれぞれ加え， $30^{\circ} \mathrm{C}$ で 1 夜（17〜18時間）作用させたのち, その分解度を測 定した（第 3 図その 1 ，第 4 図その 2 ，第 5 図その 1 , 第 6 图その 2 )。その結果 TCA 可溶性化度によってみ ると, 供試食品のほとんどは明らかになまの方が蒸煮の
それよりもよく分解し，Asp. niger のプロテアーゼを 除いてその分解度は60～95\%に達した。Asp. niger の プロテアーゼによる場合では, なまのイボダイ, タイ, エビではむしろ蒸煮の方がややよかった。遊離アミノ基 生成度合についてもやはりなまがよく分解し，その度合 はその条件で 5 〜 10\%に達し，イカの如きはどのプロテ アーゼについても35\%以上にも達し，なまの方が蒸煮し た場合よりもはるかに分解された。 

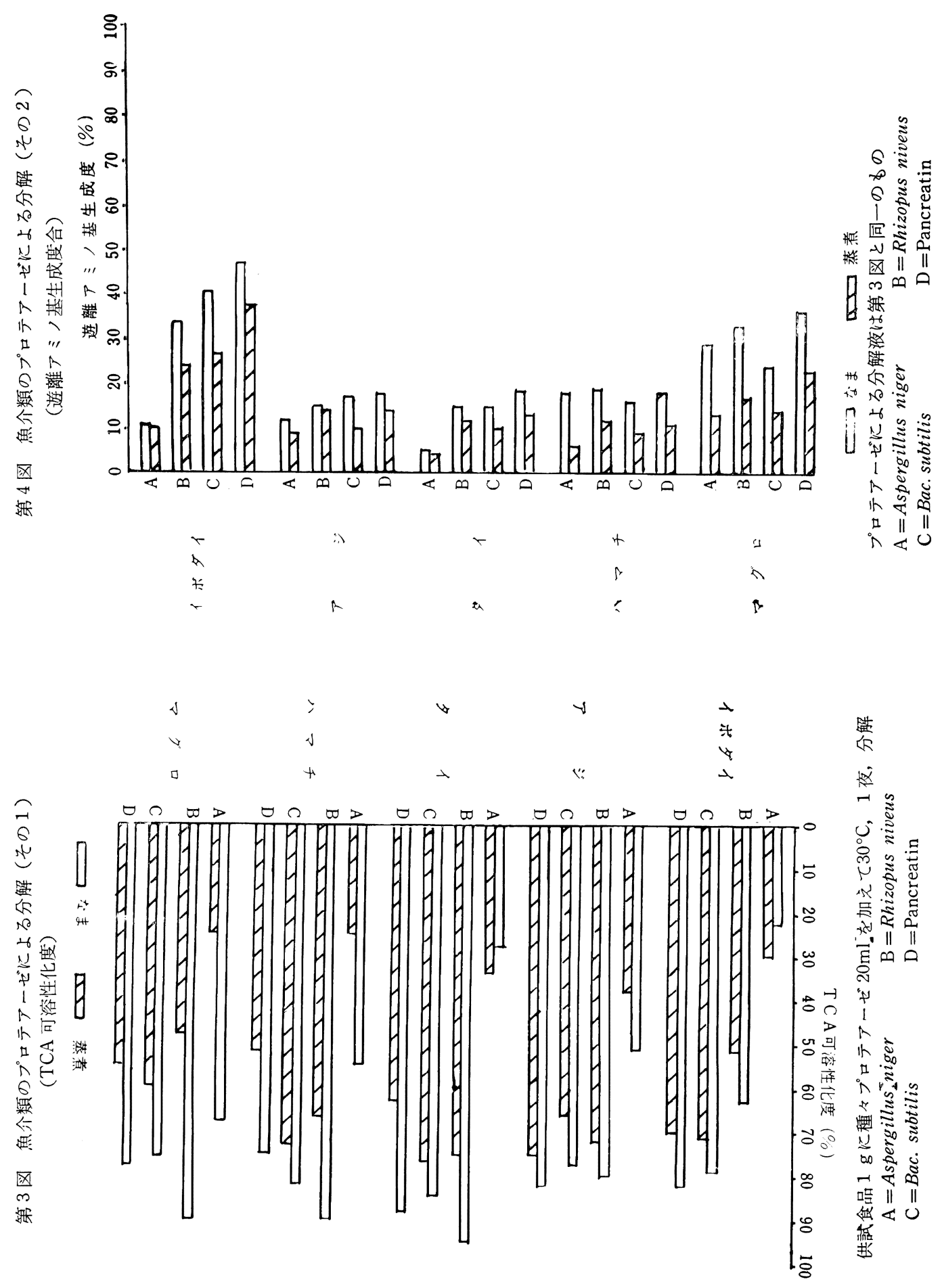

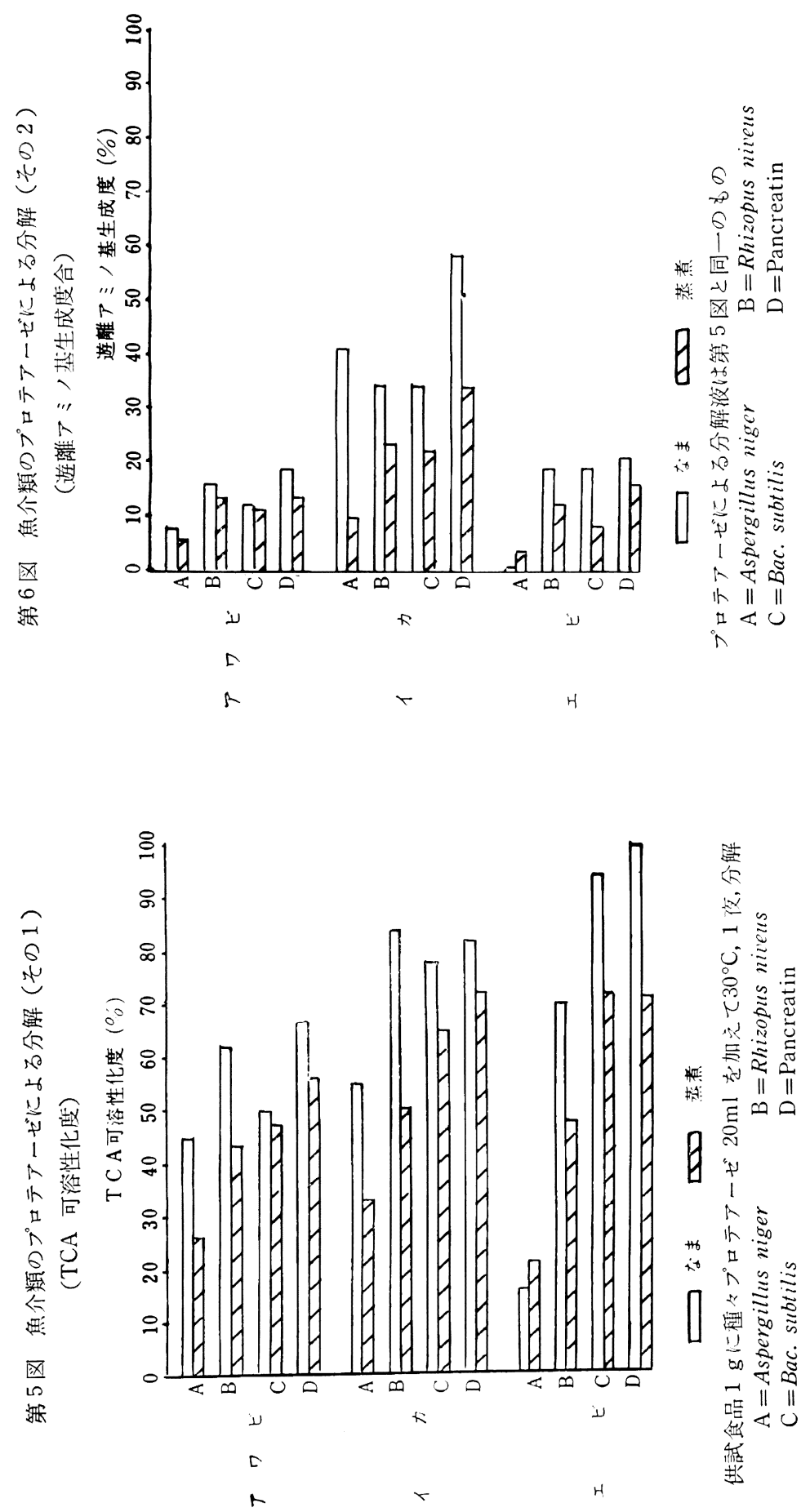

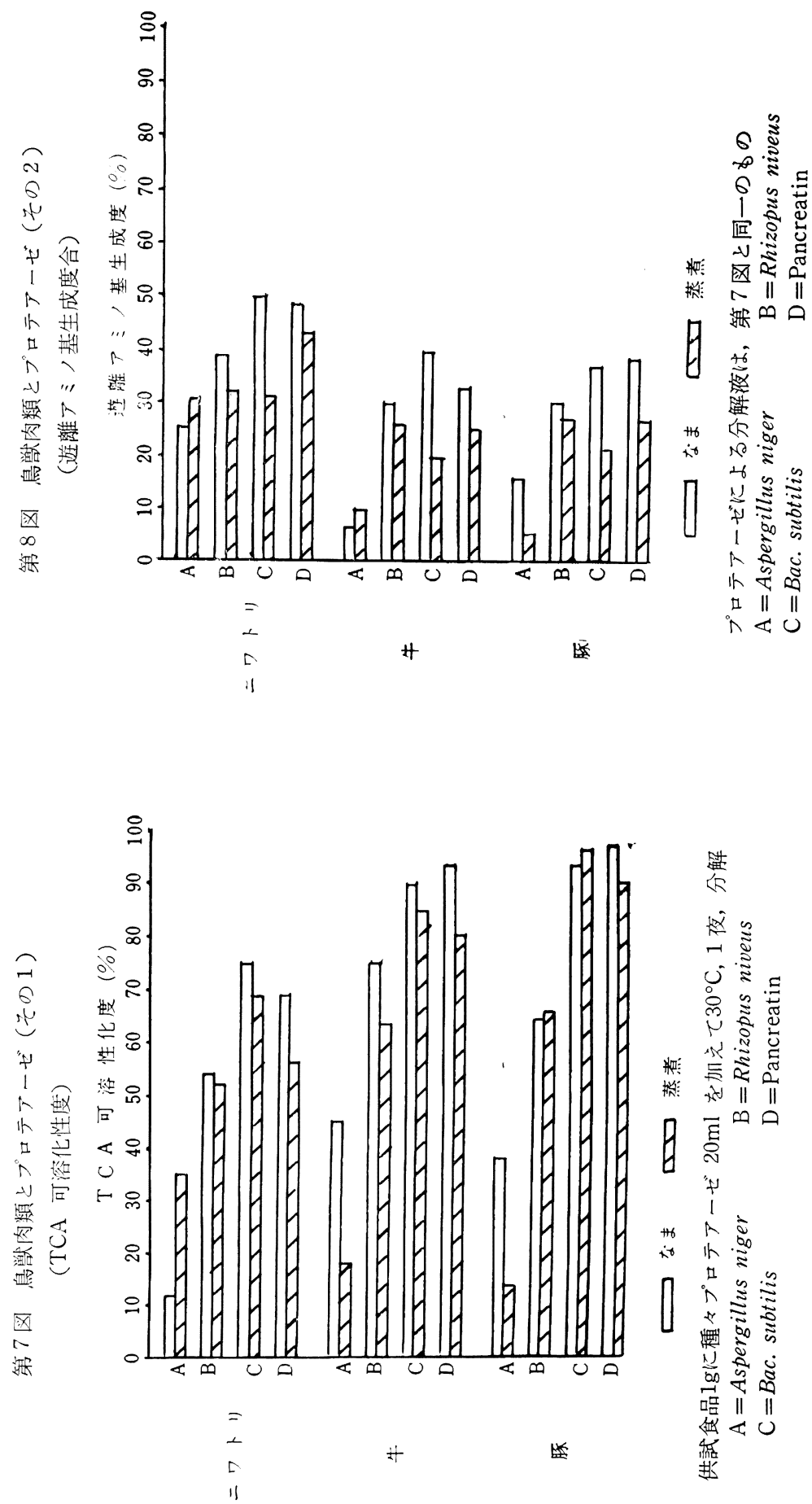

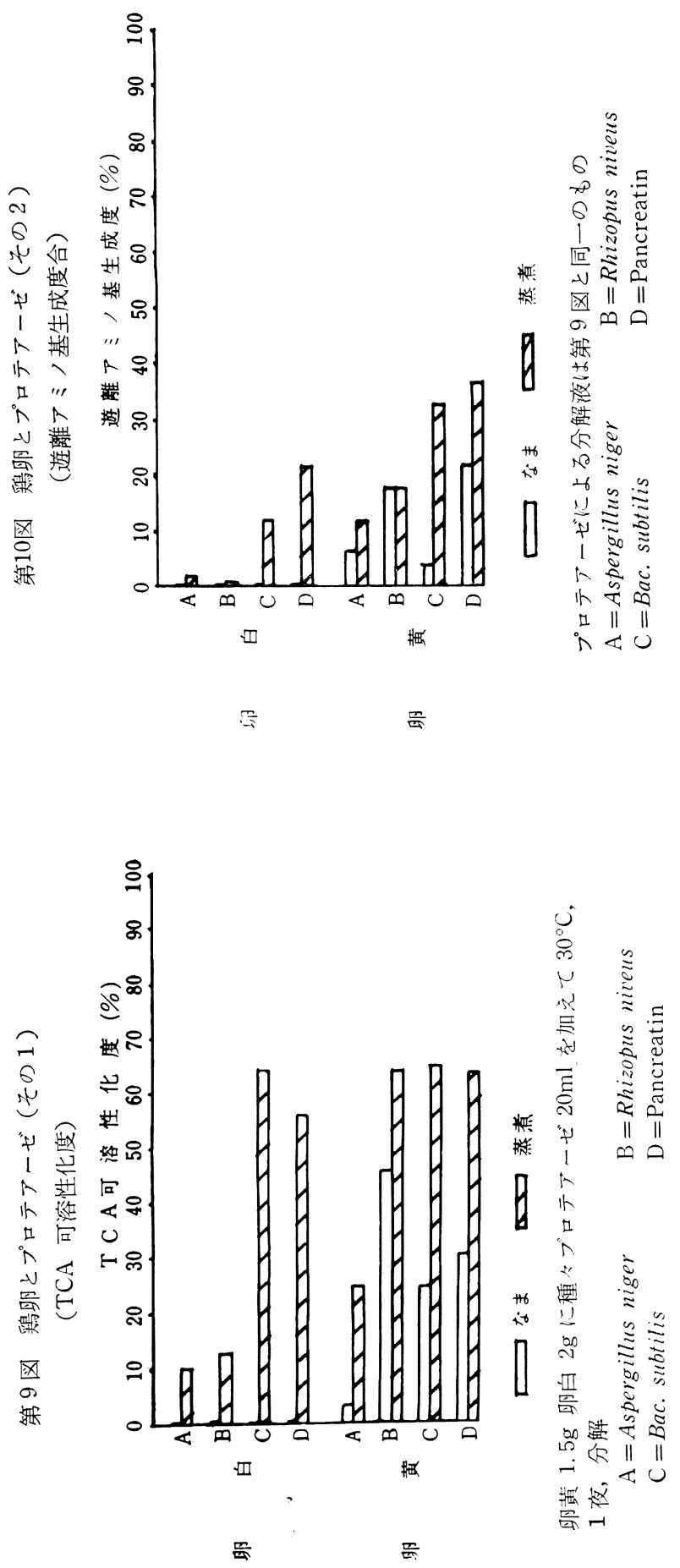

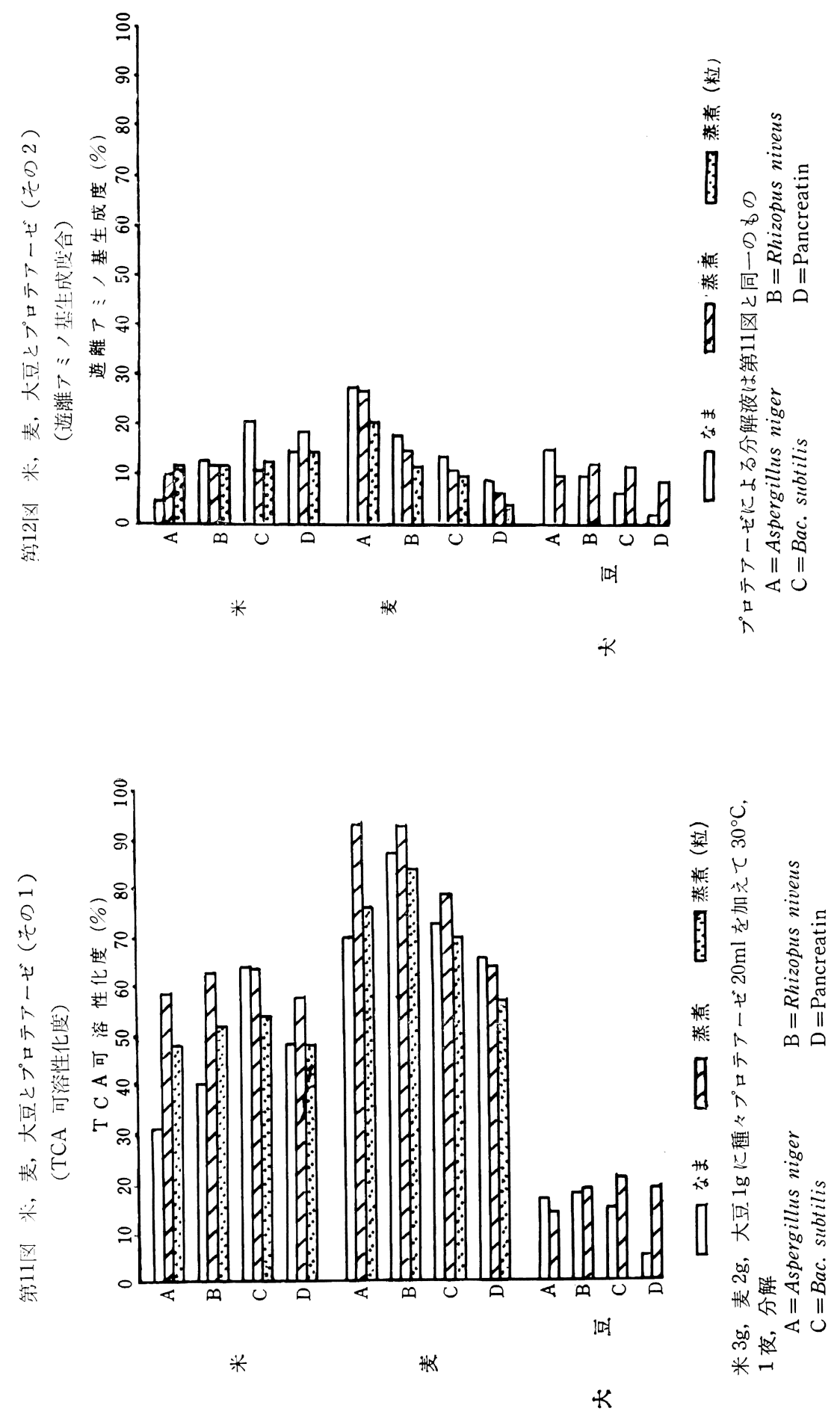


\section{II 鳥獣肉類について}

ニワトリ, 牛, 豚について魚介類と同じ条件で試験し

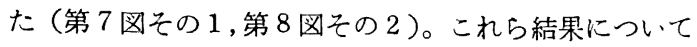
まず TCA 可溶性化度によってみると，やはりなまの方 が蒸劣よりるよく分解し，50〜95\%であった。しかしな まと蒸酋との差は魚介類の場合ほど顕著ではなかった。 またなま肉の場合 Pancreatin と Bac. subtilis とのプ ロテアーゼを用いると，その分解は極めて高かった。ま たアミノ基生成によってみた場合 Asp. niger のプロテ アーゼを例外として、いずれもやはりなまの方が蒸煮よ

り分解がよかった。

III 鷄卵について

前記同様条件で鵎卵について試験した結果（第 9 図そ の 1 , 第 10 図乞の 2$)$, 魚介類, 鳥獣肉の場合とはかな り異なり, TCA 可溶性化度によってみると, すでに明 らかにされている如く，なま卵白はどのプロテアーゼで も殆んど分解されなかった。しかし水煮すると分解され た。遊離アミノ基生成によってみてもやはり同様の結果 であった。

IV 米, 麦拉よび大豆について

前記生鮮魚介類, 鳥獣肉類など動物蛋白食品と比較す るため, 米, 麦扣よび大豆についても検討した。蒸煮米 麦では粒のままとそれをさらにつぶしたものについて試 験した（第11図その 1 ，第 12 図その 2 )。その結果米と 麦について TCA 可溶性化度によってみると, 生鮮魚介 類や鳥獣肉と異なり,なまと蒸煮との差は極めて少な く, むしろ逆に蒸煮の方がかえって良好な蛋白分解を示 した。また同じ蒸煮米麦では粒をすりつぶした方がやや その蛋白分解が大で，その分解率は約 60〜 90\%に達し た。大豆でもなまは米，麦と同梯に蒸惹した方がよかっ た。特に Pancreatin プロテアーゼではそれが顕著であ った。遊離アミノ基生成によってみても，TCA 可溶性 化度とほ泟同様の関係がみられた。

$$
\text { 考察 }
$$

蛋白質を含む斯品のプロテアーゼによる分解率は, 加 熱処理によりなまのそれよりかえって不良になるものが あることがわかった。一般にプロテアーゼによる蛋白の 分解は天然の状態ではうけ難く変性すればうけやすいこ と, そのため醉素蛋白の上うな球状蛋白の変性は枯草菌 のプロテアーゼによる分解度で定量しらることが報じ1 られている。この事実は大豆(3)4)5) や鷄卵吕 では加熱に より消化率ならびに栄着価がくなることと一致する。

しかし魚介類, 鳥獣肉類について本実験ではこれと全 く異なる結果が得られた。䋐維蛋白質を主成分とする魚 介類や肉類の酵素による蛋白分解についての研究は軟化
7) 8) 9) に関する研究以外はきわめて少なく，またいわゆる なまの状態の瀻維蛋白の消化 ${ }^{1011112)}$ もあまり明らかにさ れていない。供試魚介類や肉類のなまの状態の筋肉は, いわゆるミオシンの如き㵶維蛋白質から構成されている が，しかし本実験でいわゆるなまと述べた状態の蛋白は 生きているときのそれとはかなり相湺し，プロテアーゼ でアタックされやすい状態に蛋白分子の主体㩐造がある 程度くずされているとみなされる。蒸煮はこの状態にま で变性した魚介類や肉類をさらに収緶凝固させるため密 になり，そのためプロテアーゼの攻揧がなまよりうけに くくなったと考光られる。

食品の蛋白分解度を酵素別にみるとき，Asp. niger のプロテアーゼ以外の供試プロテアーゼはいずれも約 80 〜 90\%の分解度を示している。Pancreatin や Bac. subtilis のプロテアーゼは蛋白分解度合が比較的大である ことが知られて打り，事実本実験に打けるごとく食品に 対して十分多量に酵素を使用した場合，䖽白はほとんど 供試醅素の分解限度近くまで進むことがみられた。

なお，本実験に用いた Asp. niger のプロテアーゼは 魚介類や肉類においては他のプロテアーゼより分解度が 少ないにもかかわらず，米や麦に打いてはむしろ大であ った。これはこのプロテアーゼの特異性によるよりもこ のプロテアーゼ剤中に含まれるへミ七ルラーゼ，七ルラ 一ゼが米や麦などの組織に作用し，そのためプロテアー ゼの渗透がよくなったためこのような結果になったと思 われる。

$$
\text { 要 䄪 }
$$

数種市販プロテアーゼ剤による種々生鮮食品の蛋白分 解について検討した。

1. 生鮮鳥獣魚介類のプロテアーゼによる分解度はな まミンチ》蒸煮ミンチであった。

2. しかし鷄卵とくに卵白は蒸煮によってはじめて分 解されるに至った。

3. 米, 麦, 大豆の蛋白質も蒸煮によって蛋白分解性 がいくぶん增加した。

本研究に当たり種々ご指導いただいた, 大阪市立大学 理学部福本教授, 山本助教授に深謝いたしますとともに 醉案を供与された上田化学工業(㑣社脤, 阪急醉素(株)社 長, 日本臓器裂薬㑣研究部長に愿くお礼申上げます。な お，この報文の一部は, 第18回本学会総会において講演 した。 


\section{文献}

1) 奥貫一男, 萩原丈二, 外 3 名: 酵素化学シンポジ ウム第 9 集, 1 (1954)

2）林 寛, 有山 恒：本誌，10，37 (1957)；13， 11 (1961)

3 ) 道喜美代, 飯塚美和子：本誌，15，62（1962）

4) 道喜美代, 長谷川好空, 大上清治：農化，37, 21 (1963)

5 ) 乙坂ひで: 家政学雑誌, 11，7 (1960)

6 ) 近藤美千代：本誌，8，40 (1955)；8，5 (1956)

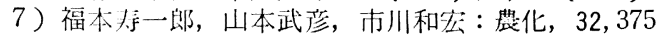

(1958)

8 ) 別所秀子, 黒沢祝子 : 本誌, 15,27 (1963) ; 16, 36 (1963)

9) Tuomy J. M. Lechnir R. J. Millert : Food Technol, 17, 119 (1963)

10）伊東きぬ忽：家政学雑誌，9，221 (1958);10,171 (1959)

11) 三浦勇吉 : 農化, 32, 486 (1958)

12) 大高文男 : 本誌, 12, 33 (1959)

(大阪女子大学)

\section{米の理化学的性質およびアミノ酸組成}

16 品種の槏米（インディカ 12 品種, ジャポニカ 4 品 種）について一般成分の分析を行ない，㣍種と成分間の

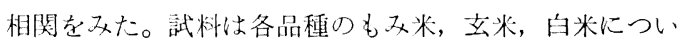
て行なった。一般的にい党ば、インディカはジャポニカ よりも理化学的品質に扣いてはばがあるといえる。また 白米については種々の調理適性:試験を行ない, 化学成分 との相互関倸を㭇钨した。括もな测定項目は糊化温度, アルカリテスト，ヨード侕洒である。

由米16種，立米 3 種について、アミノ酸の分析を行な った。测定はアミノ酸自動分析汒によった。白米のタン パク含且とアミノ酸含量との間には, リジン, メチオニ ン，スレオニンについては值の相関がみられ，チロシ ン, アルギニン， ロイシンについては正の相関がみられ た。白米のアミ)酸組成（タンパク中平均，\%)は, ア
ラニン6.28， アルギニン8.94， アスパラギン酸10. 88 , シ スチン1. 12, グルタミン酸 23.19 ，グリシン 5.10 , ヒス チジン 2.58 , イソロイシン 4.69 , ロイシン 9.47 , リジン 4. 00 , メチオニン1.98, フェニルアラニン6.06, プロリ ン 5. 34, セリン 5.72 ，スレオニン 3.99 ，チロシン 3.65 , バリン6.16であった。

(表 8)

Studies on the Physicochemical Properties of Rice.

by Juliano, B. O., Bautista, G. M., Lugay, J. C., Reyes, A. C., :

J. Agr. Food Chem., 12, 131 138 (1964) 